\title{
The role of the organizational champion in achieving health system change
}

\begin{abstract}
In healthcare there is a long held wisdom that 'champions' are a key aspect of organizational change. Drawing on organizational management theory, we examine the role of champions in three health and social care organizations in England as they attempt to move services to a remote model of delivery. The delivery of remote care is a significant policy in the UK and elsewhere, but its introduction has been challenging. Over three years ethnographic methods were used to analyse the role of organizational champions in implementing remote care. Cases were local authorities and associated primary care trusts. Participants were champions and organizational members involved in implementation.
\end{abstract}

Our study shows that organizational champions are highly effective in the first phase of adoption, when change is contained within distinct sub-sets of practice. Moving beyond local contexts the effectiveness of the champions varied. Identification centred on the remote-care work. This identification enabled the champions to motivate others and move beyond their normally prescribed roles, contributing to innovation ideas, processes and practices. When required to shift their work organization-wide, and share ideas outside their professional culture, some champions responded with resistance, resulting in a lack of innovation spread.

These results caution against allowing change to become positioned within the remit of a few individuals. Whilst this strategy may be initially beneficial, the role of champion may be less useful, even detrimental to progress, in the later stages of implementation, particularly if identification with the new circumstances is not established. 


\section{Background}

Attempts to produce transformational change across health systems to meet the challenges of rising demand and limited resources demonstrate the difficulties of introducing of new ways of working in healthcare (Ferlie, Hartley \& Martin 2003; McNulty \& Ferlie 2004; Hendy, Fulop, Reeves, Hutchings \& Collin 2007). It is increasingly acknowledged that integrating complex process innovations into existing health systems is hard, in that they are often only workable in highly context-specific ways (Pettigrew, Ferlie \& Mckee 1992; Plesk \& Greenhalgh 2001; Robert, Greenhalgh, MacFarlane \& Peacock 2009). In part, this stems from the different values, cultures, beliefs and identities of the various professional groups involved (Ferlie, Fitzgerald, Wood \& Hawkins 2005; Currie, Fin \& Martin 2008).

Alongside this awareness of the complex and context-dependent nature of change, is a renewed focus on 'social influence' theories of organizational change. This theme runs through work on innovation adoption, where product champions act entrepreneurially to engage themselves and others with the innovation (e.g. Rogers 1995). In health management, the essential role of the champion and opinion leader is also acknowledged (Soo, Berta \& Baker 2009; Greenhalgh, Macfarlane, Bate \& Kyriakidou 2004; Locock, Dopson, Chambers, \& Gabbay 2001; Dobson, Fitzgerald, Ferlie, Gabbay, \& Locock 2010), alongside evidence for their effectiveness (Schon 1963; Backer \& Rogers 1998; Markham 1998). The research suggests that champions enable formal hierarchies and professional divisions to be circumvented. Yet, as Greenhalgh et al., (2004) note, little direct empirical evidence exists on how to harness the benefits and energy of champions. Questions remain about what factors determine their success. 
The idea of the organizational champion as a vehicle for social influence is not new (Beath 1991; Schon 1963; Meyer \& Goes 1988). In defining a champion, we use Howell \& Higgins (1990) definition. The champion, at least initially, emerges spontaneously and informally within an organization (cf. Schon, 1963) and actively and enthusiastically promotes innovation and change to others for the good of the organization (Mantere 2005; Howell \& Shea, 2001). In Schon's words (1963 p.84) champions “identify with the idea as their own, and with its promotion as a cause, to a degree that goes far beyond the requirements of their job”. This definition is useful in reflecting a personal commitment to the role, as opposed to emphasising expertise or seniority (Locock et al 2001).

A major aspect of the champions' role is to influence and facilitate change in others. Champions do this by demonstrating commitment, promoting innovation with passion and persistence, pulling together diverse groups of professionals, team-building, and developing informal networks to support them (Pettigrew, Ferlie \& Mckee, 1992; Maidique, 1980; Schon, 1963). Importantly, they communicate meanings attached to the innovation to organizational members, and involve and motivate others to do the same, acting as boundary spanners between top management and other members (Carlile, 2002).

Howell and Higgins (1990) report that champions are distinguishable by their ability to communicate a clear vision of the innovation. This process is described in organizational literature as sensegiving, the ability to create understandings in others that accommodate new organizational goals (Gioia \& Chittipeddi, 1991; Maitlis \& Lawrence, 2007). Information for sensegiving is gathered and used in many forms; conversations, documents, storytelling, behaviours and actions (Balogun \& Johnson 2004). On an emotional level sensegiving can help establish identification, an intertwined understanding, with new elements of the 
organization becoming embedded in employees’ self-concept (Pratt, Rockman \& Kaufman 2006).

With sensegiving comes sensemaking (Gioia \& Chittipeddi, 1991; Maitlis \& Lawrence, 2007; Gioia Thomas, Clark, \& Chittipeddi 1994). Sensemaking is a narrative process through which a mental model of the world is created, shared and maintained (Mohammed \& Dumville 2001). Research on the development of sensemaking and shared mental models suggests that the development of team goals, and identification with work roles is usually positive - particularly so in healthcare organizations, where good team work is an essential component of effectiveness (Baker, Day \& Salas 2006).

Ease in sensegiving and the development of shared understandings is connected with homogeneity. Because sensegiving is a social process, it is often enhanced when the sensegiver and recipient share educational, professional, and cultural backgrounds (Fennell \& Warnecke 1988; Fitzgerald Ferlie, Wood, \& Hawkins 2002). Work on shared mental models has shown that this unity, although useful, may over time become problematic (Mohammed, Ferzandi \& Hamilton 2010). Group members need to agree and disagree, simultaneously, in order to maintain needed balance and flexibility. A very closely shared group schema can become a liability, with the group jointly refusing to abandon consensually validated, but organizationally ineffective, views of the world (Klimoski \& Mohammed 1994).

The problematic nature of homogeneity is further highlighted in the work of Ferlie et al (2005). The study shows that adoption is easier when the innovation or change is contained within small homogenous groups. Knowledge diffuses within the group, but will fail to diffuse across boundaries and get stuck, when values are not shared. Ferlie et al (2005. 
p.129), explains that "the presence of strong professional roles and identities makes it even less likely that knowledge will flow across social boundaries”. This raises an interesting question; if a champion highly identifies with an innovation, and shares this sensemaking with the team, how does this consensus impact on the team's ability to spread the innovation outwards. Unfortunately, the authors do not pursue the answer. For elaboration we need the work of sensemaking and identity theorists.

To varying degrees people derive a sense of who they are from the organizations and work groups to which they belong (Hogg \& Terry 2000). People need to situate themselves with reference to others, but in large organizations there may be a multiplicity of available groups nested or embedded within each other (e.g. workgroup, professional group, division and the wider organization) (Ashforth \& Johnson 2001). By internalising the group or organization as part of oneself, the individual member gains a sense of meaningfulness and connection to others and a coherent sense of who they are. Strong organizational identification or “perceived oneness with a group” (Ashforth \& Mael 1989 p.35; Elsbach 1999) is more likely within more exclusive, concrete and proximal groups. Thus, in a large company identification with your specific work group is more salient than identification with the wider organization.

Gioia \& Chittipeddi (1991), Pratt, Rockman \& Kaufman (2000) and Fiol (2002) explain that organizational change, such as the introduction of an innovative model of healthcare delivery, can trigger changes that disrupt the basis of organizational identification. The organization may need to evolve, and change its internalised structure, in terms of what it stands for and where it intends to go. These changes require associated shifts in organizationally shared values and attitudes (Ashforth \& Mael 1989), with aspects of member identification becoming redundant or destroyed (Fiol 2002). For example, if a specific work practice is 
invalidated by changes in organizational policy, members need to re-establish themselves inline with the new work practice (Pratt, Rockman \& Kaufman 2006; Ravasi \& Schultz 2006).

So, in effectively implementing organizational change, champions need to make sense of the change by re-identifying with the new context, before sharing the change via their sensegiving with others. Our first research question is how do champions re-identify with new change? Can identification be re-established, through sensemaking, to fit with changes brought about by an innovation? Our second question is how do champions establish reidentification in others? Do champions, through their sensegiving abilities, allow other members to embrace change, so enabling innovation adoption? To answer these questions we need to consider the changing nature of organizational identification and the type of identity work (sensemaking and sensegiving) that needs to be done, over a period of substantial organizational change.

\section{Research context and design}

An area where the work of champions is particularly prominent is in the development of remote care, commonly called 'telecare'. Telecare systems are used to monitor patients with chronic conditions, such as diabetes, or in the case of a frail elderly person, act as motion sensors, so an incidence such as fall in the home is relayed remotely to a call centre. These systems have been around for over a decade, but have been slow to spread (Barlow, Bayer \& Curry 2006). The systems are politically attractive but often clinically or economically contentious. Simply put, this is an area of innovation where champions need to work hard to persuade others of the potential of this technology (May et al. 2003). The difficulty of implementation also means remote care provides comparative longitudinal cases 
studies of champions, and their work, as they attempt to reposition remote care as a routine and taken-for-granted part of healthcare.

We undertook purposive sampling to find organizations most likely to develop remote care services during the funding period of a government initiative, the Preventative Technologies Grant (April 2006-9). To decrease contextual differences we identified three cases in England, closely aligned in terms of their desire and ability to implement remote care (from a national sample of 151 local authorities in England). The cases presented here were assessed by a Department of Health expert as national 'front-runners' - all three sites had at least two years experience in running and evaluating remote care trials, and had provided evidence of organizational (chief executive officer, CEO) and financial support for the change (assessed thorough publicly available documents). Another criterion was for each case to have at least one dedicated and experienced champion. We identified these champions before the start of the study by informally interviewing staff identified as such by others, i.e. individuals who were enthusiastically promoting remote care in a manner that was described as transcending their immediate working responsibilities. All our champions had worked informally to promote remote care for at least two years preceding the study. Interestingly, by the start of the study the champions had moved into more formal remote care roles, due to their previous commitment to the innovation and the new funding (see table 1 for details).

Sampling was done by publicising the research on a national telecare website, meetings with experts, conferences, visits, phone calls, databases, interviews with champions, and from project documentation. To enhance generalisability, demographic variability was taken into account. For a description of the cases (see table 1). 


\section{Data collected}

We were given full access to the sites and we attended as many key events relating to remote care implementation as possible. We used interviews and a range of ethnographic methods to gather data (Emerson, Fretz, \& Shaw, 1995). Over the course of the study we conducted 68 hours of interviewing, 41 hours of informal discussions and meetings, and 50 hours of observations.

The research question is primarily concerned with whether the champion's organizational identification is re-established to fit with changes brought about by an innovation. The champions were formally interviewed at least twice across the course of study (we also met with them informally at their work place many times over the study period). Interviews concerned how they viewed and enacted their role, the sites' remote care position, likely future position, the interviewees' motivations, commitment and actions, and the commitment of others they communicated with.

We were also concerned with whether, through their sensegiving capabilities, champions enabled re-identification in others, aiding innovation adoption across the organization. To fully understand the champion's sensegiving we needed to take into account the views of those collaborating, and working with the champion. We decided to interview all staff in champion's work group. The staff had usually been actively recruited by the champion to help with implementation. We also interviewed staff outside these work groups. These were members who had an active role in managing change because of their formal position, ranging from the CEO and project managers, to directors of service, commissioners, senior practitioners and clinicians. Interviewees were identified via the champion, and other organizational members, through snowballing, and from publicly available documents. 
Interviews contained questions regarding the sites’ remote care position, the interviewees’ relationship with the champion and their work roles, motivations, commitment and actions within this context.

To supplement the interview data, we attended project group meetings, strategic meetings and observed team decision-making. We also examined available documents such as annual reports and management minutes.

\section{Data analysis}

The analysis progressed in five stages. Firstly, we developed a detailed picture of each case and their history concerning how previous remote care efforts had progressed. This work provided a baseline from which progress could be assessed. We then began building a story. Strauss \& Corbin (1990) suggest beginning with a fine-grained reading of the data 'microanalysis'. We began by writing a detailed account of the change from the viewpoint of the champions. We sought to give an account of what had transpired in the context in which events took place. We catalogued and temporally ordered the data, and used official sources to construct an event history. We proceeded to integrate the views of the champions with different stakeholders by using non-public texts and interview data. As the richness of our data allowed for triangulation, we augmented, criticised and structured the champions' view with this other data.

During the third analysis stage, we coded the data on the basis of the theoretical account we had taken, with induction balanced against our theoretical framing of issues such as sensemaking and identification. A pictorial summary of the coding process was produced. The framework then guided further fieldwork and data collection, but we were cautious not to 
be de-sensitised. We used evolving findings to consider the efficacy of our conclusions, then went back to the data to determine the suitability of these themes. The result was constant movement.

We identified and coded instances of the champions’ sensegiving and employee responses. This allowed us to identify texts that corresponded to a large number of empirical codes ('open coding'; Strauss and Corbin 1990). During the fourth analysis round, we structured the data into more distinct categories addressing the type of sensemaking and identification 'work' that was being conducted, and the impact of this on the organization (Pratt, Rockman \& Kaufman 2006). Finally, during the fifth stage, we integrated the previous rounds into a temporal explanation of identification, sensemaking and sensegiving, introducing our theoretical vocabulary into this framework.

While our account is one of many interpretations, the rigorous practice we followed helped us avoid fitting the data to predefined ideas. Our conclusions were validated by an independent analyst who coded a selection of randomly chosen extracts (about 20\%). A high level of agreement was achieved. Our findings were further validated by being presented to the cases, and at conferences attended by representatives from local care providers and industry. There was broad agreement with our interpretations.

\section{Results}

For reasons of confidentiality we have omitted the real names of our three study sites, instead we identify them within the paper as $\mathrm{C}, \mathrm{N}$, and S respectively. Examination of previous remote care progress at each site demonstrated that levels of penetration were similar at the start of the research (see table 2). This suggests that the organizational champions were 
similarly effective in the first phase of adoption. When the sites attempted to reposition remote care as a routine part of the healthcare system, variation emerged. This could be seen in the number of people in each case using remote care over time. User numbers increased significantly in case $\mathrm{N}$, moderately in $\mathrm{C}$, and decreased in site $\mathrm{S}$ (table 2). The lack of progress in case $\mathrm{S}$ was surprising, as they had $£ 1.5 \mathrm{~m}$ of funding, an experienced and committed champion, and a team of supporters. To understand reasons for the lack of progress we need to unpack the chronology of events.

In the early stages of adoption, the involvement of the champions appeared wholly beneficial. The establishment of earlier projects meant all the champions had been previously involved in remote care activities, but on a much smaller scale. This early work enabled strong identification with the work, "To succeed (at remote care implementation) means everything to me, it's all what I'm about" "this is my life's work, what I live and breath, I am remote care”. This connection with the work encouraged them to motivate others, and move beyond their normally prescribed roles, contributing to innovation ideas, processes and practices.

Over time identification became more salient, partly due to a range of supportive organizational actions. "We could be at the front of something, be at the cutting edge, and why not, it's a good thing to do. We'd get a buzz out of it and maybe some kudos." The champions were allowed travel to conferences and attend government policy meetings. They were encouraged to demonstrate how they had achieved uptake, were given control over funding, and prestigious new titles (see table 1). In this early stage sensegiving to others was prevalent. The champions in all sites were active in persuading small groups of organizational members within their community to adopt the innovation. 
The later move from trial projects, run by the champions and a close group of supporters, to organization-wide implementation required a significant shift in ownership of the work. New stakeholders needed to be involved, with new remote-care groups formed. Many staff involved in remote care work, not just the champions, found this challenging: "Social workers sitting alongside nurses, sitting alongside doctors and housing officers - that was part of our attempt to try and break down some of these organizational boundaries. But ... there's a lot of people find that very uncomfortable.... not sure about the letting go of power, letting go of responsibility. Can I trust you?"

For the champions there was a feeling that they no longer maintained exclusive rights to the work. In site S where numbers decreased, the champion (Dan) particularly struggled with the changes. He needed to share the work, and potentially lose this exclusive aspect of his identity. He expressed his distress, and that he alone was responsible for previous successes: "they need to realise that if they got rid of me the programme would collapse because I'm everything, I'm very closely identified with it."

Being seen as a pivotal part of the remote care implementation had become a preferred and salient self-conception (Ibarra, 1999; Thornborrow \& Brown, 2009), a valued source of selfesteem. Dan's identification was threatened by the changes but he was unprepared to make the necessary adjustments the new work required. Sensemaking and sensegiving were no longer centred on engaging in the remote care work but on maintaining his position: “As the telecare strategist, I didn't receive any formal recognition of that. Salary, grade, job title, didn't really reflect that. Now the senior management has got involved, possibly because there's money floating around, now things have changed and I don't want to lose that new autonomy” 
Dan expressed that the continuity and future of his role and his team were in jeopardy, but instead of working to align himself with the new context he created a 'sense' break between himself and the values of the organization, which he clearly articulated.

"If you take the most basic level you have organizational values. The organization says you must have these values... And you have the personal values that people who work in the organization have. People rarely check or match between the two. What we're getting at the moment is the organizational values are interchangeable but the personal values remain different in the staff who work within them. So you have people disengaging from the organizational values because there is this conflict"

This ‘sense break' was reinforced by discrediting the new organizational strategy and managerial input. Sensegiving was no longer focused on persuading others to embrace the innovation, but on undermining and creating scepticism for the new scheme whilst legitimating his existing self-conception. Through these actions Dan lost support of the CEO and gained a reputation as a 'trouble maker'. Destructive aspects of his sensegiving spread and served to undermine other staff members’ attempts at alternative sensemaking. “I adopted (Dan's) approach that either you come along or you stay away, but either way it's going ahead, with you or without you. Now with the money we have tiers of management who want a hand in its direction. So, we are all going to have a bit of a battle and struggle to keep it here."

Dan and a group of his supporters formed a united team. A battle mentality emerged, a 'them and us' divide that had not existed before. Over time Dan and his team made no attempt to 
widen participation. There was a lack of cooperative spirit, an embattled attitude which led to a reversal in remote care uptake (see table 2, case S).

When trying to spread the innovation more widely the three champions in case $\mathrm{C}$, where progress was moderate, also found the transition difficult. Previously, they had been active in small initiatives in different areas. This division of labour enabled sensegiving over a wide number of stakeholders, and aided diffusion. Hence, when the CEO decided to spread the work to encompass the entire community the decision was well received. The CEO's actions further reinforced the work of the champions, and with his blessing they set about buying large amounts of remote care equipment. However, this spending was poorly received by other staff. Rather than being seen as working for the good of the organization they were now perceived as working 'for themselves' and lacking integrity.

“(T)hose people focus on the equipment and buying things because it looks good... but what are you going to do with it? They don't actually know! It was toys for boys, and I'm sceptical...you have to do a lot of work to integrate that technology into the actual service delivery to achieve the value"

Subsequently, implementation slowed, creating an imperative for new sensegiving. The champions had close links with those in their immediate work groups, but were both unwilling and unable to communicate beyond these groups. Again we found that ownership of the remote care work created competition between the champions, their supporters, and other 'outsiders’ (see Hogg \& Terry 2000). The champions were unwilling to identify with the change in context, remaining wedded to existing ways of doing things. The CEO expressed concern: "I'm still concerned that stuff is being lost. Promotion activity that is going on should be countywide, and these people just have gone off and done their own little 
thing and no one else really knows about it. To be honest they like to hold on to their own little kingdoms..."

Animosity between the champions, their supporters, and 'outsiders' gained momentum. In desperation, the CEO stepped in and created two new remote care posts, aimed at bridging the gap and further supporting the change. The posts were filled by established internal members, who had their duties reassigned. The creation of these support posts gave needed legitimacy to the work of the three existing champions (see Gioia et al 1994).

The action enabled the work to be once more seen as integral to the whole organization. The new sensegiving moved remote care away from previous dialogues concerning 'extravagant spending' and implementation progressed well. The role of the existing champions was changed to emphasise a wider focus. The champions responded differently to this change. One left, expressing that he was too unhappy to stay. The other two champions decided to stay but their work was now heavily supported by the new staff:

"We're on the journey of trying to change our approach; how we communicate this outwards, how we're dealing with our resources, how we try and create and provide opportunities for people to be more independent. And it's about the role of what we can offer them in support of that"

In case $\mathrm{N}$, where change was most successful and where user numbers increased dramatically, the champion (Chuck) was not officially an internal member of staff, but had worked within the organization on change management for some years, so was generally viewed as an integral member (see Birkinshaw, Hamel \& Mol 2008). Chuck worked 
tirelessly to promote remote care because he believed it could transform the lives of people. This passion influenced the CEO, and paved the way for a radical programme of change.

Chuck's identification was not situated with a specific group within the parent organization. He saw himself as a 'free agent', an advocate for remote care, with portable skills. This lack of organizational identification allowed him to quickly set about dismantling the existing scheme. Previous ways of operating were seen by Chuck as areas of rigidity and dysfunction: They are a bunch of middle ranking accountants who make it extremely difficult to run with all out activity. With simple things they say oh, we can't do that now. Well it's all change. I'm so fed up with their short-term stupid attitude and I'm not putting up with it.

Unlike the champions in other cases, Chuck expressed that his task was to enable others to become involved. Giving away responsibility for remote care did not challenge his selfconcept, but was seen as a fundamental part of his work: "it's all about creating that excitement, creating that commitment that then gains momentum after I've gone. It's about building up, then being able leave and everything continues on"

Chuck and his team worked hard to provide new meanings for the organization's employees, and reduce any anxiety related to the changes. Their aim was to create an environment that included as many members as possible in the new endeavour from inception: I wanted to sort out the infrastructure, to engage people better than had previously been the case... I think that people operationally and on the ground were too far removed from it. It is really important to have input at a local level as well as at a strategic level. I still think it's a challenge to get everybody embracing telecare across the whole of an organization. 
Sensegiving activities were mobilised on a huge scale, with different managerial strategies employed at different phases of implementation. In the early phases rhetorical and symbolic strategies were widely used to build a 'shared language and vision' and organization-wide commitment. New names were given to the initiative, and media and marketing campaigns were started. Sensegiving focused on persuading stakeholders to embrace the change, with remote care positioned as an exciting development. Staff started to think of themselves as part of the scheme and inclusion quickly became a desired goal.

\section{Discussion}

Organizations must adapt to environmental change, with champions viewed as part of an armoury of strategies to ensure the organization's vision and identity are effectively managed alongside this change (Howell \& Higgins 1990). By the nature of their role, champions should sell, promote and encourage alignment with an innovation. Underlying these arguments are several assumptions. Firstly, that changes in manager identification occur, secondly that managers go on to induce such modification in other members, and thirdly that this process is vital to organizational success. Using case studies of remote care implementation, the study set out to explore these assumptions; whether champions reidentified with changes in context, brought about by wide-scale implementation of the innovation. We then sought to explore whether through their sensegiving abilities, the champions could enable such changes in others.

In the adoption of innovations Birkinshaw, Hamel \& Mol (2008) define the role of key change agents in terms of four distinct processes. According to their typology, the champions in our study were effective in driving the first two processes; motivating others and experimenting with new practices within their own workgroups. The other two processes, 
implementation and making sense of the innovation, required the champions to move beyond their local context. Other stakeholders both inside and outside the organization needed to be part of this work, and here the effectiveness of the champions varied hugely.

Some of the champions in our study perceived the involvement of other stakeholders as a threat to their status. This was expressed by a lack of engagement and by resisting input from others, regardless of whether this was beneficial for the wider organization (Balogun \& Johnson, 2004; Gioia \& Chittipeddi, 1991). As discussed, within a large organization, identification can be situated within a multiplicity of available groups (Ashforth \& Johnson 2001). Identification within these groups may be nested, with some more subjectively important and situationally relevant, that is more salient than others. Usually, identification with so called lower order groups (i.e. job and workgroup) is more salient than higher order groups (i.e. department, division and organization-wide). For example, identification with a workgroup is more exclusive, has finer grained local meanings, and the impact is more direct (Lawler 1992).

We noted that identification quickly formed within lower order remote-care work groups, reinforced by organizational actions. Top managers were particularly pivotal in crafting organizational accounts that gave legitimacy and authority to the champions' work (Suchman 1995). This authority was reinforced by the new resources available via the government funding, and new job titles and roles. Subsequently, this emerging innovation provided the champions with new leverage (see Maguire, Hardy \& Lawrence 2004). From having a few followers, informal limited authority and resources, the champions now had formal authority, powerful followers, and the funds to back them up. Subsequently, the remote-care work became highly prized. 
For the champions in our less successful cases, $\mathrm{C}$ and $\mathrm{S}$, maintaining their immediate connection to the work and protecting their role in directing this work, became important. Identification with high order groups, concerning the wider values and mission of the organization, was less apparent. Sensegiving was focused on maintaining their existing position.

These actions are somewhat contradictory to the existing literature, which would predict that changes in context would induce the champions to de-identify with the old and re-identify with the new (Pratt, Rockman \& Kaufman, 2000; Fiol 2002). Instead, the changes associated with organization-wide implementation were perceived as a threat (Pratt et al 2006); with the champions working to maintain identification with the extant position. These results are also contrary to the underlying assumption that greater engagement and identification with a change process or innovation increases the likelihood of adoption and organizational change (Brown \& Duguid 1991; Wenger 1998). The development of identification may be useful in early phases of adoption, when communicating with similarly minded colleagues (Fennell \& Warnecke 1988; Fitzgerald et al. 2002), but our research suggests in the later phases of implementation strong levels of identification can be destructive. Powerful individuals may not be able, or want to, adapt to the new context. Instead they direct organizational sensegiving in ways that are coherent with protecting their existing self.

In further understanding how these actions impact on implementation, shared mental model literature is useful (Mohammed, Ferzandi \& Hamilton 2010). As explained earlier, this theory explains how the champion's sensegiving can form a framework for understanding change that is shared across a work team (Mohammed \& Dumville 2001). This shared understanding 
and associated identification within the team is often positive, leading to increased group cohesiveness and effectiveness (Baker, Day \& Salas 2006), but very closely shared understandings can also become a liability (Klimoski \& Mohammed 1994 p.419).

In the unsuccessful case S, the champion's high level of identification with the extant schema was successfully shared across the team. When the spread of the innovation required other stakeholders to be included, the shared sensemaking and identification made the champion's task of undermining and creating scepticism for the new scheme easier. The champion was trusted by the team, his sensemaking was considered legitimate and the sensegiving resonated (see Maguire, Hardy \& Lawrence 2004). The champion, via new sensegiving, successfully transferred a sense of threat to other members of the team.

In case S, the champion's largely peripheral position within the organization, and the wide range of diffuse stakeholders involved in implementation further helped consolidate his increasingly isolated position (see Rowley 1997). Initially, he and his team’s insular behaviour went unnoticed, giving the champion and his workforce time to further coalesce and form a united front that prevented further strategic movement. All later attempts to alter managerial control, with organization-wide standards and procedures, were negatively communicated and largely ignored. The impact on remote care implementation was devastating; despite the $£ 1.5 \mathrm{~m}$ funding, there was a reduction in remote care users from 300 to 233.

From these findings we can conclude that the champions' need to continue to highly identify with and protect their existing position had detrimental organizational consequences. However, we cannot do away with organizational identification. Staff members will not be 
motivated to engage in any level of sensemaking and sensegiving if identification with the organization and their work is not present at some level. This is what Fiol (2002) calls the identity paradox; strong organizational identification is likely to blind people to new possibilities, but with no identification why would they care? The question is under what conditions can identification be successfully managed and re-established for achieving organizational change?

When we take a closer look at case $\mathrm{N}$ the champion strongly believed in remote care but identification was not grounded in doing remote care work. Identification was expressed in terms of his personal management skills, which were seen as both constant and portable. His aim was to use his skills to educate and implement, then move on. This lack of organizational connection allowed him to set about sharing and giving away responsibilities for implementation without feeling he was giving away a valued part of himself.

These results suggest you can have a champion that is able to shift implementation to include all interested and relevant stakeholders. Such individuals have been defined as having “liminal identities” (Zabursky \& Barley 1997), in that they identify with no particular group but occupy positions that are easily transferable across organizations. Research on liminal identification is limited but with the move towards short-term transactional contracts and the increasing frequency with which people change careers, it seems likely that many more individuals will not identify with an organization or group, but with their own skills.

\section{Conclusions}

There is a long held wisdom that organizational champions have a necessary and positive impact on organizational change (Locock et al 2001). Our findings question these 
assumptions. Our work suggests that the champion's ability to identify with changes in context is not a given. For the champions in our study, their own identification was so entwined with their current role that they worked to maintain this role, clinging to the existing schema for self-enhancement purposes and continuity, rather than moving forward.

Strong identification with the extant role was partly enabled by the organization. By formulating plans that exploited the champion's enthusiasm and motivational drive, the top management created attractive opportunities for self-enhancement. Our findings suggest that in creating these opportunities, there needs to be caution. Success in developing champions that strongly identify with a particular stage of organizational change can be deleterious to progress later on. Attempts to undo this sensemaking and identification, and provide a new strategic vision, may be inhibited by prior successes. Earlier sensemaking may linger, and be resilient to removal, particularly if the champion perceives that they are losing a desired part of themselves (Ibarra 1999).

Perhaps champions need to highly identify with their role for them to "identify with the idea as their own" and go on to promote innovation "far beyond the requirements of their job" (Schon 1963 p.84). If so, our results suggest that managers need to utilise their skills, but also ensure that their work and role is bounded, centred on the start of the innovation journey when garnering early support is required. As Locock et al (2001) tentatively suggest, champions may do their most important work at the inception stage, when they are communicating a vision rather than implementing a reality. Their role in the practicalities of implementation may be less useful, even detrimental to progress. At this point it may be necessary to hand over to other organizational members, with different perceptions, identities 
and skills more appropriate for managing pragmatic issues of implementation (see Soo et al 2009).

Finally, healthcare organizations need to be clear about the challenges in achieving change. As Pettigrew, Ferlie \& McKee (1992) point out, in successful implementation the development of a 'critical mass' of onboard members is ultimately important, rather than the efforts any single heroic individual or group of champions. That said, our study suggests the reverse is also important - individual ‘champions’ do have the ability to seriously derail organizational change efforts. 


\section{References}

Ashforth, B. E., \& Mael, F.A. (1989). Social identity theory and the organization. Academy of Management Review, 14, 20-39.

Ashforth, B. E. \& Johnson S. A. (2001). Which hat to wear? The relative salience of multiple identities in organizational contexts. In Social Identity Processes in Organisational Contexts. Eds. M. A. Hogg \& D. J. Terry. Philadelphia: Psychology Press.

Backer, T.E., \& Rogers, E.M. (1998). Final report - Diffusion of innovations and the Business Responds to AIDS Program. Human Interaction Research Institute, Los Angeles. $(\mathrm{H}-92)$.

Baker, D. P., Day, R. \& Salas, E. (2006). Teamwork as an essential component of highreliability organizations. Health Services Research, 41 (4),1576-1598.

Balogun, J., \& Johnson, G. (2004). Organizational restructuring and middle manager sensemaking. Academy of Management Journal, 47 (4), 523-549.

Barlow, J., Bayer, S., \& Curry R. (2006). Implementing complex innovations in fluid multistakeholder environments: experiences of 'telecare’. Technovation, 26, 396-406.

Beath, C. M. (1991). Supporting the Information Technology Champion. MIS Quarterly, 355-372. 
Birkinshaw, J., Hamel, G. \& Mol. M. J. (2008). Management Innovation. Academy of Management Review, 33 (4), 825-845.

Brown, J. S., \& Duguid, P. (1991). Organizational learning and communities of practice: Towards a unified view of working, learning and innovation. Organization Science, 2, 40-55.

Carlile, P. R. (2002). A Pragmatic View of Knowledge and Boundaries: Boundary Objects in New Product Development. Organization Science, 13 (4), 442-455.

Currie, G., Finn, R. \& Martin, G. (2008). Accounting for the ‘dark side’ of new organizational forms: The case of healthcare professionals. Human Relations, 61 (4), 539564.

Dobson, S., Fitzgerald, L., Ferlie, E., Gabbay, G., \& Locock, L. (2010). No magic targets! Changing clinical practice to become more evidence based. Health Care Manage Review, 35 (1), 2-12.

Elsbach, K.D. (1999). An expanded model of organizational identification. In B.M. Staw, and R.I. Sutton (Eds.), Research in Organizational Behavior, 21, 163-200. Greenwich, CT: JAI Press

Emerson, R., Fretz, R., \& Shaw, L. (1995). Writing Ethnographic Fieldnotes. University of Chicago Press. Chicago. 
Fennell, M. L., \& Warnecke. R. B. (1988). The Diffusion of Medical Innovations: An Applied Network Analysis. Plenum: New York.

Ferlie, E., Hartley, J., \& Martin, S. (2003). Changing public service Organizations: Current perspectives and future prospects. British Journal of Management, 14, S1-S14.

Ferlie, E., Fitzgerald, L., Wood, M. \& Hawkins C. (2005). The nonspread of innovations: The mediating role of professionals. Academy of Management Journal, 48 (1), 117-134.

Fiol, M. (2002). Capitalizing on paradox: The role of language in transforming organizational identities. Organization Science, 13 (6), 653-666.

Fitzgerald, L., Ferlie, E., Wood, M., \& Hawkins. C. (2002). Interlocking Interactions, the Diffusion of Innovations in Health Care. Human Relations, 55 (12), 1429-49.

Gioia, D. A., \& Chittipeddi, K. (1991). Sensemaking and sensegiving in strategic change initiation. Strategic Management Journal, 12 (6), 433-448.

Gioia, D. A., Thomas, J. B., Clark, S. M., \& Chittipeddi, K. (1994). Symbolism and strategic change in academia: The dynamics of sensemaking and influence. Organization Science, 5 (3), 363-383.

Greenhalgh, T., Robert, G., Macfarlane, F., Bate, P., \& Kyriakidou. (2004). Diffusion of innovations in service organizations: systematic review and recommendations. Milbank Quarterly, 82, 581-629. 
Hendy, J., Fulop, N., Reeves, B.C., Hutchings, A., \& Collin, S. (2007) Implementing the NHS programme for information technology: a qualitative study of progress in acute trusts. BMJ. 334, 1360-8.

Hogg, M. A., \& Terry, D. J. (2000). Social identity and self-categorization in organizational contexts. Academy of Management Review, 25 (1), 121-140.

Howell, J. M., \& Higgins, C. A. (1990). Champions of technological innovation, Administrative Science Quarterly, 35, 317-41

Howell, J. M. \& Shea, C. M. (2001). Individual differences, environmental scanning, innovation framing and champion behaviour: Key predictors of project performance. Journal of Product and Innovation Management, 18 (1), 15-27.

Ibarra, H. (1999). Provisional selves: Experimenting with image and identity in professional adaptation. Administrative Science Quarterly, 44, 764-791.

Katz, D., \& Kahn, R. L. (1966). The social psychology of organizations. New York: John Wiley.

Klimoski, R. \& Mohammed, S. (1994). Team mental model: Construct or metaphor? Journal of Management, 20 (2), 403-437. 
Lawler, E. J. (1992). Affective attachments to nested groups: A choice process theory. American Sociological Review, 57, 327-339.

Locock, L, Dopson, S., Chambers, D. \& Gabbay, J. (2001). Understanding the role of opinion leaders in improving clinical effectiveness. Social Science \& Medicine, 53, 745-757.

Maidique, M. A. (1980). Entrepreneurs, champions and technological innovation. Sloan Management Review, 21 (2), 59-76.

Maitlis, S., \& Lawrence, T. B. (2007). Triggers and enablers of sensegiving in organizations. Academy of Management Journal, 50 (1), 57-84.

Mantere, S. (2005). Strategic practices as enablers and disablers of championing activity. Strategic Organization, 3, 157-183.

McNulty, T., \& Ferlie, E. (2002). Reengineering health care: the complexities of organizational transformation. Oxford, England: Oxford University Press.

Markham, S.K. (1998). Longitudinal examination of how champions influence others to support their projects.” Journal of Product Innovation Management, 15 (6), 490-504.

May, C. Mort, M. Williams, T. Mair. M \& Gask. L (2003). Health technology assessment in its local context: studies of telehealthcare. Social Science \& Medicine, 57, 697-710. 
Meyer, A. D. \& Goes, J. B. (1998). Organizational assimilation of innovations: A multilevel contextual analysis. Academy of Management Journal, 31(4), 897-923.

Mohammed, S. \& Dumville, B. C. (2001). Team mental models in a team knowledge framework: expanding theory and measurement across disciplinary boundaries. Journal of Organizational Behavior. 22, 89-106.

Mohammed, S., Ferzandi, L \& Hamilton, K. (2010). Metaphor no more: A 15-year review of the team mental model construct. Journal of Management, 36 (4), 876-910.

Pettigrew, A., Ferlie, E. \& McKee, L. (1992). Shaping strategic change - The case of the NHS in the 1980s. Public Money \& Management, 27-31.

Plsek, P. E. \& Greenhalgh, T. (2007). Complexity science: The challenge of complexity in health care. BMJ, 323, 625-628.

Pratt, M. G., Rockmann, K. W., \& Kaufmann, J. B. (2006). Constructing professional identity: The role of work and identity learning cycles in the customization of identity among medical residents. Academy of Management Journal, 49 (2), 235-262.

Robert, G. Greenhalgh, T., MacFarlane F. \& Peacock, R. (2009). Organisational factors influencing technology adoption and assimilation in the NHS: a systematic literature review. Report for the National Institute for Health Service Research Delivery and Organisation Programme. SDO Project (08/1819/223). HMSO. 
Rogers, E. (1995). The diffusion of innovations. (4 $4^{\text {th }}$ ed.). New York: Free Press.

Rowley, T. J. (1993). Moving beyond dyadic ties: A network theory of stakeholder influences. Academy of Management Review, 22 (4), 887-910.

Schon, D. A. (1963). Champions for radical new inventions. Harvard Business Review, 41, 77-86.

Soo, S.,Whitney, B., \& Baker, R. (2009). Role of change champions in the implementation of patient safety practice change, Healthcare Quarterly, 12, 123-128.

Strauss, A. L. \& Corbin, J. (1990). Basics of Qualitative Research, Thousand Oaks. CA: Sage.

Suchman, M. C. (1995). Managing Legitimacy: Strategic and Institutional Approaches. The Academy of Management Review, 20 (3), 571-610.

Thornborrow, T. \& Brown A. D. (2009). 'Being regimented': Aspiration, discipline and identity work in the British Parachute Regiment. Organization Studies, 30 (4), 355-375.

Wenger, E. (1998). Communities of Practice: Learning, meaning and identity, New York: Cambridge University Press. 
Zabusky, S. E. \& Barley, S. R. (1997). You can’t be a stone if you're cement: Reevaluating the emic identities of scientist in organizations, In B.M. Staw, and R.I. Sutton (Eds.), Research in Organizational Behavior, 19, 361-404. Greenwich, CT: JAI Press. 
Table 1. Background to the cases

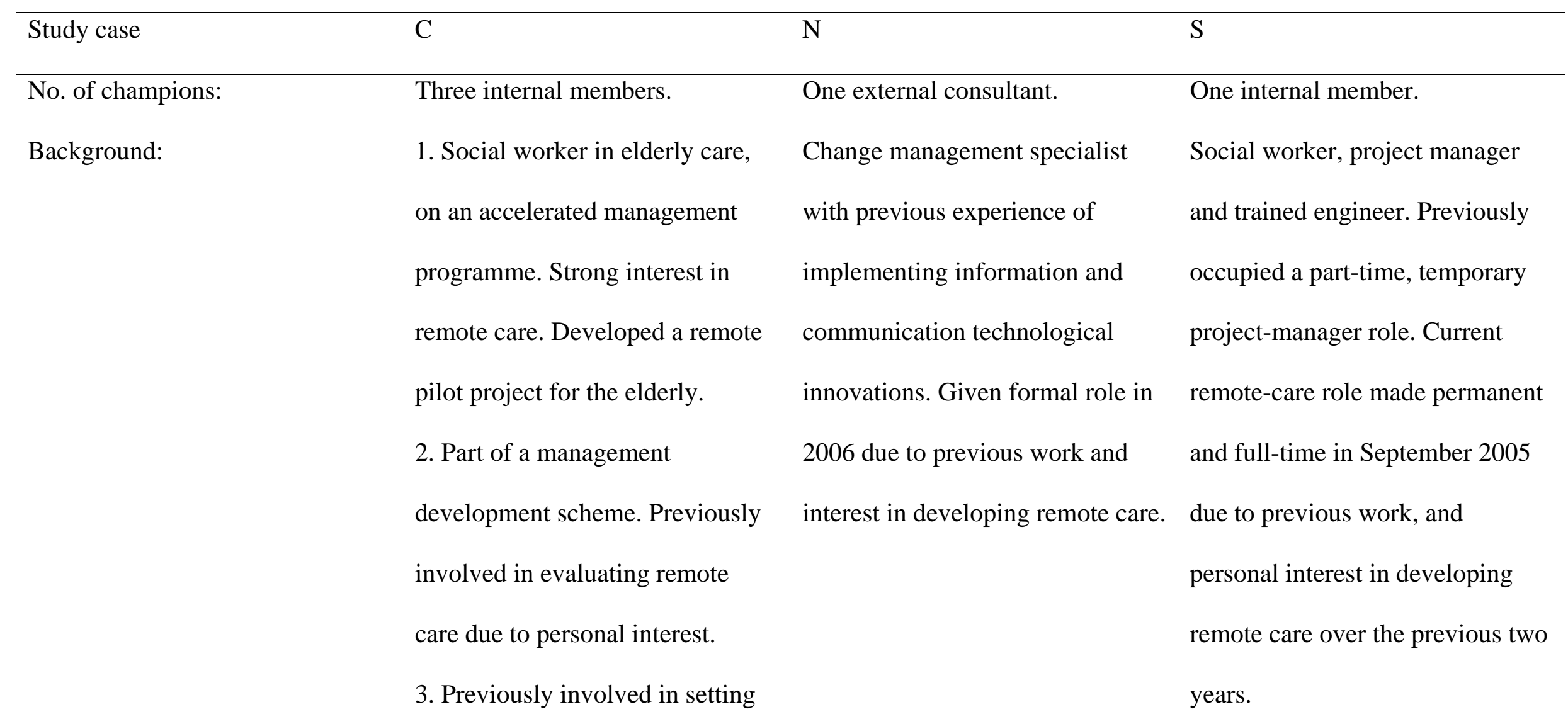

up a remote care working group. 
Champions were given formal

roles in late 2005/ early 2006.

Title:

$$
\text { elderly. }
$$

2. Implement remote care for

those with chronic conditions and

develop remote care

infrastructure.

3. Set up evaluation schemes, staff

training and support.

\section{Develop remote care organization Develop remote care organization} wide. wide.

Management strategy: Jun 2006 - Allocate funding to support three

Being with remote care for the

Spend funding on increasing the 
existing remote-care pilot sites. elderly and those with chronic

Simultaneously support spread

diseases.

across the rest of the district. profile of the implementation

team, then develop remote care

for the elderly, those with learning

disabilities and for diabetics with

matched funding from the

Primary Care Trust.

\begin{tabular}{|c|c|c|c|}
\hline Remote care pre. 2006 & $\begin{array}{l}\text { Monitoring sensors for the elderly } \\
\text { and those with learning } \\
\text { disabilities since } 2003 \text {. }\end{array}$ & $\begin{array}{l}\text { Monitoring sensors for the elderly } \\
\text { since } 2004 \text {. }\end{array}$ & $\begin{array}{l}\text { Monitoring sensors for the elderly } \\
\text { and motion sensors for the blind } \\
\text { since } 2003\end{array}$ \\
\hline Demography & $\begin{array}{l}\text { Large county in Southern England } \\
\text { with a mixture of rural and urban } \\
\text { settlements. }\end{array}$ & $\begin{array}{l}\text { London borough with social } \\
\text { deprivation and high levels of } \\
\text { elderly people. Ethically mixed } \\
\text { population. }\end{array}$ & $\begin{array}{l}\text { Metropolitan borough council. } \\
\text { Large urban settlement. Strong } \\
\text { Asian community. }\end{array}$ \\
\hline Structure of care services & $\begin{array}{l}\text { Two tiered authority. Health } \\
\text { separate from social care and } \\
\text { housing. }\end{array}$ & $\begin{array}{l}\text { Unitary authority, health, housing } \\
\text { and social care are integrated. }\end{array}$ & $\begin{array}{l}\text { Unitary authority, health housing } \\
\text { and social care are integrated. }\end{array}$ \\
\hline
\end{tabular}


rating 2004/5

Pop. in 100,000 - census 2001

Table 2. Implementation progress

\begin{tabular}{llcc}
\hline Case & C & N & S \\
\hline Grant funding 2006-8 & $£ 1,988,751,475,876$ \\
\hline No. of users Jun. 2006 & 310 & $£ 390,715$ & 300 \\
\hline No. of users Jun. 2008 & 1,450 & 2,401 & 233 \\
\hline
\end{tabular}

